\title{
Dari Pithecanthropus Ke Homo Erectus: Situs, Stratigrafi, dan Pertanggalan Temuan Fosil Manusia di Indonesia
}

\section{Harry Widianto}

Keywords: chronology, java, hominin, distribution, dispersal

\section{How to Cite:}

Widianto, H. (2006). Dari Pithecanthropus Ke Homo Erectus: Situs, Stratigrafi, dan Pertanggalan Temuan Fosil Manusia di Indonesia. Berkala Arkeologi, 26(2), 114-129. https://doi.org/10.30883/jba.v26i2.936

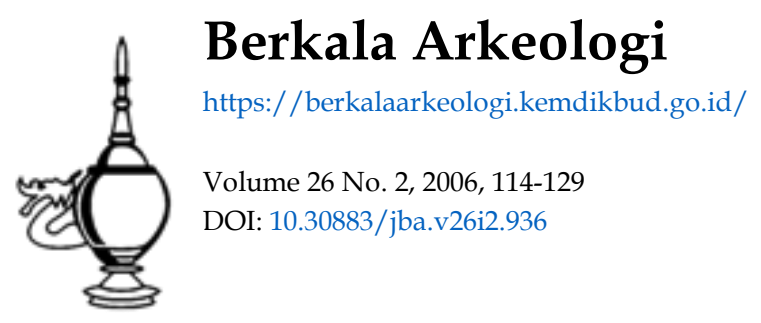

\section{c) (7) (2)}

This work is licensed under a Creative Commons Attribution-NonCommercial-ShareAlike 4.0 International License. 


\title{
DARI PITHECANTHROPUS KE HOMO ERECTUS : Situs, Stratigrafi, dan Pertanggalan Temuan Fosil Manusia di Indonesia
}

\author{
Harry Widianto
}

\begin{abstract}
Pulau Jawa merupakan satu-satunya tempat penemuan fosil manusia purba di Indonesia. Penemuan-penemuan yang berlangsung di berbagai situs tersebut telah menjadikan pulau ini sebagai salah satu wilayah terpenting di dunia dalam penelusuran asal-usul dan evolusi manusia. Temuan pertama manusia purba pada tahun 1891 yang akhirnya melegenda di dunia - Pithecanthropus erectusberasal dari endapan volkanik Kala Plestosen Tengah di jajaran Pegunungan Kendeng di Trinil, Ngawi, yang telah menjadikan polemik panjang pada akhir abad 19. Temuan spektakuler di masa itu berupa atap tengkorak yang sangat primitif, disertai dengan sebuah tulang paha kiri yang mengesankan pemiliknya telah berjalan tegak. Penemuan pun kemudian tetap berlangsung hingga akhirakhir ini, antara lain melalui temuan sebuah fragmen kranial manusia bagian belakang sebelah kiri, yang berasal dari endapan grenzbank di Glagahombo, Sangiran pada bulan Juni 2005 (Widianto, 2006). Antara temuan pertama dan terakhir tersebut, lebih dari 100 individu manusia purba ditampilkan dari berbagai endapan purba di Pulau Jawa, yang situs-situsnya terletak pada berbagai bentang fisiografi, yaitu : cekungan besar Solo (Sangiran dan Miri), endapan volkanik Pegunungan Kendeng (Trinil, Kedungbrubus, dan Perning di Mojokerto), endapan alluvial Bengawan Solo (Ngandong, Sambungmacan, dan Ngawi), serta endapan volkanik Gunung Muria (Patiayam).
\end{abstract}

Migrasi manusia di Pulau Jawa itu diperkirakan baru berlangsung pada Plestosen Bawah dari daratan Asia, yang mungkin berasal dari Afrika. Satu pertanyaan penting kemudian muncul : apakah Pithecanthropus telah sampai di Pulau Jawa pada Kala Plestosen Bawah yang dimulai sejak 1.8 juta tahun yang lalu ? Secara teoritis sangat mungkin, seandainya dihubungkan dengan munculnya spesies ini di 
Afrika pada 1,7 juta tahun lalu. Pada saat itu, Paparan Sunda telah menjadi lalu lintas migrasi antara Jawa dan daratan Asia. Di lain pihak, pada komponen breksi bawah, telah ditemukan pula fosil-fosil binatang kontinental, seperti buaya (van Es, 1931) dan Cervidae (Koenigswald, 1940). Untuk Situs Sangiran misalnya, angka 1,65 juta tahun merupakan batas bawah lapisan Pucangan, dan dianggap sebagai usia maksimum, sehingga hominid pertama di Formasi Pucangan di Sangiran jelas lebih muda dari 1,65 juta tahun.

\section{- Dari Pithecanthropus erectus ke Homo erectus}

Temuan fosil Pithecanthropus erectus oleh Dubois telah dipublikasikan sejak tahun 1894 dalam berbagai majalah ilmiah. Dia menyatakan bahwa, menurut teori evolusi, Pithecanthropus erectus -bentuk peralihan antara manusia dan keramerupakan moyang manusia. Masyarakat ilmiah pun kemudian menjadi skeptis : atap tengkorak dengan volume otak yang kecil, gigi-geligi berukuran besar, dan tulang paha yang berciri modern, apakah berasal dari satu individu? Sementara orang menduga bahwa tengkorak tersebut merupakan tengkorak seekor gibon, gigi-geligi merupakan milik Pongo sp., dan tulang pahanya milik manusia modem. Lima puluh tahun kemudian terbukti bahwa gigi-geligi tersebut memang berasal dari gigi Pongo sp. Berdasarkan ciri-cirinya yang berukuran besar, akar gigi yang kuat dan terbuka, dentikulasi yang tidak individual, dan permukaan oklusal yang sangat berkerut-kerut (de Terra, 1943).

Debat mengenai Pithecanthropus erectus dari Dubois berlanjut di Eropa ketika Dubois mempresentasikan penemuan tersebut dalam seminar internasional zoologi pada tahun 1895 di Leiden, Belanda, dan dalam pameran publik British Zoology Society di London. Banyak ahli tidak ingin melihat temuannya lagi, sehingga Dubois menyimpan seluruh fosil tersebut, sampai akhimya dia menunjukkan kepada Franz Weidenreich pada tahun 1922, yang mulai menelitinya. Penemuan-penemuan di atas menandai paleoanthropologi telah lahir di Indonesia.

Antara periode kerja pertama Dubois dan Perang Dunia II, selama sekitar 50 tahun, berbagai temuan penting fosil manusia terjadi: mandibula Mauer pada tahun 1907, tengkorak Broken Hill pada tahun 1921, kemudian juga ditemukan 
tengkorak-tengkorak dari Ngandong pada tahun 1931-1932, tidak jauh dari Trinil. Tahun 1920-an merupakan tahun-tahun luar biasa bagi teori evolusi manusia. Teori ini berdenyut kencang, para ahli paleontologi berbicara tentang ontogenesa dan heterokronis (Widianto, 1993). Salah seorang teman sebangsa Dubois, yaitu Bolk, telah memformulasikan teori foetalisasi yang sangat terkenal. Dubois telah menemukan fosil missing link, Bolk telah menemukan modalitas evolusi dengan menafsirkan bahwa peralihan dari kera ke manusia terjadi melalui perpanjangan perkembangan foetal. Jembatan ini tersingkirkan, Dubois dan Bolk saling bertemu dalam jalur evolutif dari Haeckle yang sangat terkenal: bahwa phylogenesa dan ontogenesa sama sekali tidak dapat dipisahkan. Penemuan-penemuan bertambah gencar sejak tahun 1927 : penggalian di situs Zhoukoudian, dekat Beijing, menghasilkan sejumlah besar fosil-fosil manusia, yang diberi nama Sinanthropus pekinensis. Tengkorak-tengkorak fosil beserta tulang paha tersebut menunjukkan ciri-ciri yang sama dengan Pithecanthropus erectus.

Untuk membedakannya dengan Homo sapiens, manusia-manusia fosil itu kemudian mendapatkan nama-nama berbeda: Homo heidelbergensis dari Eropa, Homo rhodesiensis dari Afrika, Homo soloensis dari Indonesia, dan Sinanthropus pekinensis dari Cina. Emst Mayr (1950), seorang spesialis klasifikasi biologis, menyatakan bahwa standar zoologis tidak memungkinkan memisahkan Pithecanthropus erectus dan Sinanthropus pekinensis dalam genus yang berbeda dengan manusia modem. Pithecanthropus adalah suatu tahapan dalam proses evolusi ke arah Homo sapiens, dengan kapasitas tengkorak yang kecil. Oleh karenanya, perbedaan tersebut semata-mata hanya merupakan perbedaan spesies, dan bukan merupakan perbedaan genus. Dalam pandangan ini, Pithecanthropus erectus harus diletakkan dalam genus Homo, dan untuk mempertahankan nama spesies aslinya, dinamakanlah Homo erectus (Mayr, 1950; Campbell, 1965). Maka berakhirnya debat panjang mengenai Pithecanthropus dari Dubois dalam sejarah manusia yang telah berjalan puluhan tahun.

\section{- Situs, Stratigrafi, dan Pertanggalannya}

Situs-situs penemuan manusia purba beserta jenis-jenis manusia, lapisan tanah, dan perkiraan umurnya dapat dijabarkan sebagai berikut di bawah ini. 


\section{- Situs Sangiran, Sragen dan Karanganyar, Jawa Tengah}

Sangiran merupakan sebuah kompleks situs yang terletak di Cekungan Solo, di sebelah timur Gunung Lawu. Wilayah situs membentang di sepanjang 8 kilometer pada arah utara-selatan dan 7 kilometer arah timur-barat, dalam wilayah Kabupaten Sragen dan Karanganyar, Jawa Tengah. Situs dulunya merupakan sebuah kubah raksasa yang tererosi di bagian puncaknya, sehingga membentuk cekungan besar dengan perbukitan bergelombang. Kondisi deformasi geologis ini menyebabkan tersingkapnya berbagai lapisan batuan yang mengandung fosil-fosil manusia purba dan binatang. Sangiran merupakan situs manusia purba dari Kala Plestosen yang paling lengkap dan paling penting di Indonesia, dan bahkan di Asia. Sejak ditemukan oleh GH.R von Koenigswald pada tahun 1934, situs ini telah menorehkan gambaran panjang mengenai evolusi Homo erectus selama lebih dari 1 juta tahun terakhir. Sejak tahun 1936 fosil-fosil Homo erectus ditemukan secara sporadis dan berkesinambungan pada situs ini.

Fosil-fosil manusia, binatang, dan artefak ditemukan dalam seri geologisstratigrafis yang diendapkan tanpa terputus selama lebih dari 2 juta tahun. Penemuan-penemuan ini telah menjadikan Sangiran sebagai situs yang sangat penting bagi pemahaman evolusi manusia, lingkungan, dan budayanya, sehingga situs ini secara resmi pada tahun 1996 dimasukkan sebagai Warisan Dunia, yang tercantum dalam nomor 593 Daftar Warisan Dunia (World Heritage List) UNESCO.

Pada bagian bawah, terutama di bagian tengah situs, terdapat lapisan lempung biru dari Formasi Kalibeng dengan kepurbaan 2.4 juta tahun, menunjukkan lingkungan laut dalam di akhir Kala Pliosen (Sémah, A.M, 1982; 1986). Analisis pollen menunjukkan bahwa laguna pada saat itu dibatasi oleh hutan bakau lebat. Tidak ditemukan mamalia kontinental pada lapisan Kalibeng.

\section{Formasi Pucangan}

Aktivitas volkanik di sekitar 1.8 juta tahun yang lalu telah mengendapkan lahar tebal di Cekungan Solo, yang sebagian mengisi laguna Sangiran. Letusan gunung api ini telah merusak hutan bakau dan mengubah bentang alam menjadi laut dangkal. 
Di atas lahar, ditemukan seri endapan lempung, yang sebagian besar berupa lempung hitam, dinamakan Formasi Pucangan (Duyfjes, 1936). Formasi yang mengandung gastropoda ini di beberapa tempat mencapai ketebalan 15 meter. Pollen hutan bakau absen pada lapisan ini, sebaliknya ditemukan unsur tanaman yang mencirikan lingkungan hutan tropis lembab dan hutan terbuka, akibat musim kering berkepanjangan. Seri stratigrafi yang berusia antara 1.8 hingga 1.0 juta tahun lalu ini sangat penting, karena telah memberikan beberapa fosil manusia dengan berbagai variasi morfologis yang merupakan fosil paling purba di Sangiran, dan sejumlah fosil mamalia. Fisiknya luar biasa kekar, kuat, sehingga dalam tingkatan evolusi fisik, digolongkan sebagai Homo erectus kekar. Tidak dijumpainya alatalat manusia purba pada periode ini menggarisbawahi lingkungan rawa yang sebagian besar merupakan lumpur hitam, sehingga tidak menyediakan batuan yang umum digunakan sebagai materi pokok pembuatan alat-alat. Manusia yang hidup saat itu mungkin sekali masih memakai alat-alat dan bahan yang mudah rusak, misalnya kayu dan bambu.

Sebagian besar fosil-fosil manusia dari lapisan Pucangan berasal dari bagian atas lapisan ini, seperti halnya rahang bawah Sangiran $1 \mathrm{~b}$ dan Sangiran 5 (yang pernah disebut sebagai Pithecanthropus dubius), maupun atap tengkorak Sangiran 4 yang dikenal sebagai Pithecanthropus robustus, Sangiran 13a, Sangiran 27, dan Sangiran 31. Di lain pihak, rahang bawah Sangiran 9 (Pithecanthropus C) yang ditemukan di Mandingan mungkin berasal dari interkalasi diatomit yang berada di bagian bawah lempung hitam Pucangan. Secara kronologis, rahang bawah ini merupakan fosil paling arkaik di Sangiran.

Sejak tahun 1990-an, Pusat Penelitian Arkeologi Nasional bekerjasama dengan Muséum National d'Histoire Naturelle, Prancis menemukan beberapa fosil manusia pada horison tua ini. Fragmen tengkorak Ardjuna 13 dan rahang bawah Hanoman 13 , berasal dari beberapa meter di bawah lapisan grenzbank di Ngebung. Demikian pula atap tengkorak Hanoman 1 dari Bukuran, berasal dari bagian atas Formasi Pucangan (Widianto et el., 1994). Studi paleomagnetisma menunjukkan bahwa Formasi Pucangan diendapkan pada periode Olduvai (1.7 juta tahun) hingga batas periode Brunhes/Matuyama ( 0.73 juta tahun). Pertanggalan dengan metode fis 
sion-track pada level berfosil menunjukkan usia $1.16 \pm 0.24$ juta tahun (Suzuki, et al., 1982).

\section{Grenzbank}

Dari lapisan grenzbank ini ditemukan rahang bawah Sangiran 8, yang dikenal dengan nama Menganthropus $B$ di sebelah utara Glagahombo dan juga rahang atas Sangiran $15 \mathrm{~b}$ di selatan Kali Brangkal. Beberapa spesimen lain yang ditemukan belakangan, antara lain rahang bawah Ardjuna 9, fragmen tulang paha Kresna 11, dan gigi-geligi lepas Ardjuna 18 dan Brahmana dari Ngebung (Widianto, 1993). Jenis manusia ini telah membuat alat dari batuan kersikan seperti kalsedon maupun jasper, yang bahan-bahannya berasal dari materi erosi Pegunungan Kendeng. Alatalat batu tersebut - berupa alat serpih Sangiran - ditemukan secara in situ dalam ekskavasi yang dilaksanakann di Dayu oleh Pusat Penelitian Arkeologi Nasional dan Balai Arkeologi Yogyakarta. Alat-alat batu dari lapisan grenzbank tersebut merupakan alat batu paling yang minimal berusia 800.000 tahun (Widianto, et al., 2001). Pertanggalan grenzbank ditafsirkan antara awal periode Brunhes, di sekitar 0,73 juta tahun lalu dan akhir periode Matuyama, di sekitar 0,9-0,73 juta tahun lalu. Semah mencatat bahwa grenzbank tidak selalu ditemukan di daerah Sangiran (Sémah, F., 1986).

\section{Formasi Kabuh}

Pada periode 0.7 hingga 0.3 juta tahun lalu, terjadilah letusan gunung api yang hebat, antara lain dari Gunung Lawu dan Merapi yang memuntahkan jutaan kubik pasir volkanik, material yang kemudian diendapkan oleh sungai-sungai yang ada di sekitarnya hingga menutup lapisan grenzbank. Salah satu sungai purba yang masih bertahan hingga sekarang adalah Kali Cemoro, yang mengalir di tengah situs. Aktivitas volkanik tersebut tidak hanya terjadi dalam waktu yang singkat, tetapi saling susul-menyusul dalam periode lebih dari 0.5 juta tahun hingga meninggalkan endapan fluvio-volkanik setebal tidak kurang dari 40 meter yang dikenal sebagai Formasi Kabuh. Sedimen volkanik berfasies fluviatil (pasir dengan struktur silang-siur) atau fluvio-lacustrin (pasir berlumpur) ini, berusia akhir Plestosen Bawah dan Plestosen Tengah. 
Sebagian besar fosil manusia dari Sangiran berasal dari lapisan ini, dan mayoritas merupakan fragmen tengkorak atau atap tengkorak. Fosil-fosil tersebut adalah Sangiran 2, Sangiran 3, Sangiran 10, Sangiran 12, Sangiran 17 (merupakan tengkorak utuh, lengkap dengan mukanya), Sangiran 25, Sangiran 26, Sangiran 38. Akhir-akhir ini ditemukan pula atap tengkorak dari Grogol Wetan, Tanjung, dan Bukuran.

Dibandingkan dengan fosil-fosil manusia Homo erectus kekar dari Formasi Pucangan yang berusia Plestosen Bawah, maka fosil-fosil dari Formasi Kabuh menunjukkan ciri fisik yang lebih berevolusi, sehingga mempunyai struktur yang lebih ramping. Mengingat sebagian besar fosil dari formasi ini menunjukkan morfologi khas, maka tinggalan tersebut dinamakan Homo erectus tipik, merupakan keturunan Homo erectus kekar. Dari sejumlah temuan Homo erectus dari formasi ini, terdapat 2 buah yang menjadi temuan paling mengesankan (master piece), yaitu Sangiran 17 (mewakili individu laki-laki) dan Sangiran 2 (mewakili individu perempuan).

Sangiran 17, teng-korak Homo erectus dari endapan pasir fluvio-volkanik di Pucung ini merupakan salah satu temuan terbaik, karena terdiri atas atap tengkorak, dasar tengkorak, dan muka yang masih terkonservasi dengan baik. Fosil tengkorak ini merupakan satu-satunya temuan di Asia yang masihmemiliki muka pada saat ditemukan. Sejauh ini hanya dua temuan lengkap seperti ini di dunia, lainnya dari Afrika. Oleh karenanya, aspek fisik bagian muka Homoerectus Asia hanya dapat dicermati dari Sangiran 17, sehingga tidak dapat dipungkiri bahwa fosil ini mempunyai nilai penting yang teramat besar dalam rekonstruksi muka Homo erectus yang sebenarnya. Sangiran 17 memiliki dahi yang sangat datar, tulang kening menonjol, orbit mata persegi, pipi lebar menonjol, mulut menjorok ke depan, dan tengkorak pendek memanjang. Morfologi tengkorak dengan superstruktur yang berat dan insersi otot-otot yang sangat berkembang menunjukkan individu laki-laki dewasa. Manusia purba ini hidup ketika Sangiran masih didominasi oleh lingkungan sungai yang luas, di sekitar 700.000 tahun yang lalu. 
Berbeda dengan Sangiran 17 yang menyiratkan secara kuat sebagai individu laki-laki, maka temuan atap tengkorak oleh von Koenigswald dari Sendangbusik yang dikenal sebagai Sangiran 2, merupakan individu perempuan. Hal ini ditunjukkan oleh tidak berkembangnya insersi otot otot pada tengkorak, sehingga memberikan strüktur yang relatif halus, meski tonjolan kening dan bangun tengkorak yang pendek dan memanjang menjadi atribut kuat Homo erectus baginya. Individu ini lebih ramping dari jenis laki-laki, dan merupakan wakil perempuan yang hidup pada Kala Plestosen Tengah, sekitar 500.000 tahun lalu.

\section{Formasi Notopuro}

Pada periode sekitar 250.000 tahun yang lalu, lahar volkanik dan batuan andesitik berukuran krikil hingga bongkah diendapkan lagi di Sangiran. Pengendapan lahar ini tampaknya berlangsung cukup singkat, sekitar 70.000 tahun. Di atas endapan ini kemudian diendapkan lapisan pasir volkanik. Saat ini kedua jenis batuan tersebut merupakan ciri utama dari Formasi Notopuro. Breksi dan lahar Notopuro ini diendapkan secara tidak selaras di atas Formasi Kabuh, seperti terlihat secara jelas di bagian utara dan selatan Sangiran, yang terdiri atas lahar, breksi, dan pasir. Fosil binatang vertebrata dan alat-alat batu banyak dijumpai pada lapisan ini, sementara fosil manusia belum pernah ditemukan.

\section{- Situs Kedungbrubus, Madiun, Jawa Timur}

Sukses Eugene Dubois dalam menemukan Pithecanthropus erectus tidak hanya di Trinil, tetapi telah diawali setahun sebelumnya di Desa Kedungbrubus, desa terpencil di tengah hutan jati di lereng selatan Pegunungan Kendeng. Ketika Dubois meneliti dua horison berfosil di Kedungbrubus pada tahun 1890, dia menemukan sebuah fragmen rahang yang pendek dan sangat kekar, dengan sebagian prageraham yang masih tersisa. Rahang ini menunjukkan bagian bawah yang lebar, yang jauh melampaui rahang bawah manusia modern, dan mengesankan ciri yang sangat arkaik. Meski demikian, prageraham yang masih tertancap padanya menunjukkan ciri gigi manusia dan bukan gigi kera, sehingga diyakini bahwa fragmen rahang bawah tersebut milik rahang hominid. Kelak di kemudian hari, temuan ini diumumkan sebagai individu lain dari Pithecanthropus erectus, yang disebut sebagai Pithecanthropus A. Ditafsirkan, rahang bawah 
tersebut berasal dari lapisan Kala Plestosen Tengah.

\section{- Situs Trinil, Ngawi, Jawa Timur}

Trinil merupakan sebuah desa di pinggiran Bengawan Solo, dalam wilayah administrasi Kabupaten Ngawi, Jawa Timuryang memiliki sejarah penting tentang kisah evolusi manusia, jauh sebelum Sangiran ditemukan oleh Koenigswald pada tahun 1934. Ekskavasi yang dilakukan oleh Eugene Dubois di situs ini telah membawa penemuan sisa-sisa manusia purba yang sangat berharga bagi dunia pengetahuan. Penggalian Dubois di Trinil dilakukan pada Formasi Kabuh yang ditumpangi secara tidak selaras oleh endapan alluvial Bengawan Solo pada salah satu lekukan Bengawan Solo,. Dari lapisan ini telah ditemukan atap tengkorak Pithecanthropus erectus (Trinil 2), dan beberapa buah tulang paha (utuh dan fragmen) yang menunjukkan pemiliknya telah berjalan tegak. Berdasarkan pada studi biostratigrafi de Vos (et al., 1982), usia manusia Trinil dapat disejajarkan dengan usia grenzbank atau bagian dasar Formasi Kabuh di Sangiran, sehingga fosil-fosil ini jelas lebih tua dibandingkan dengan temuan dari Kedungbrubus.

Tengkorak Pithecanthropus erectus dari Trinil sangat pendek tetapi memanjang ke belakang. Volume otaknya sekitar $900 \mathrm{cc}$, volume di antara otak kera (600 cc) dan otak manusia modem (1200-1400 cc). Tulang kening sangat menonjol, dan di bagian belakang orbit mata, terdapat penyempitan yang sangat jelas, menandakan otak yang belum berkembang. Pada bagian bela-kang kepala terlihat bentuk yang meruncing. Tidak terdapat perkembangan nyata dari relief tengkorak dalam kaitannya dengan perkembangan insersi muskuler menandakan pemiliknya menupakan individu perempuan. Berdasarkan kabumya sambungan perekatan antar tulang kepala, ditafsirkan inividu ini telah mencapai usia dewasa.

\section{- Perning, Mojokerto, Jawa Timur}

Tahun 1936, seorang penduduk yang bekerja untuk Koenigswald dan Duyfjes menemukan atap tengkorak anak-anak, berusia antara 3-5 tahun di Sumber Tengah, sekitar 3 kilometer di sebelah utara Perning. Fosil ini berasal dari endapan yang tebal dari Kala Plestosen Bawah dan Plestosen Tengah berupa pasir konglomeratan Formasi Pucangan di bagian paling 
timur Pegunungan Kendeng yang disisipi oleh endapan marin (Duyfjes, 1936). Tengkorak dicirikan oleh penyempitan tulang kening dengan bagian occipital yang meruncing, ciri kuat Homo erectus.

Kepurbaan ten̆gkorak anak-anak ini sudah sejak lama menjadi diskusi yang berkepanjangan. Sebuah pertanggalan metode Potassium-Argon oleh T. Jacob dan Curtis terhadap batu apung yang ditemukan di dekat tengkorak menghasilkan angka $1.9 \pm 0.4$ juta tahun (Jacob and Curtis, 1971). Lebih kemudian, pertanggalan dengan sampel batu apung yang diambil dari endapan dalam tengkorak, melalui mertode Argon/Argon, menghasilkan angka 1.81 juta tahun (Swisher III, et al., 1994). Walaupun banyak keraguan atas pertanggalan ini, namun angka 1.8 juta tahun untuk sementara dapat dipertahankan hingga terdapat pertanggalan lain yang lebih dapat dipertanggungjawabkan.

Meski aspek fisiknya masih belum berkembang secara penuh karena masih merupakan atap tengkorak anak-anak yang berusia sekitar 5 tahun, aspek fisik tengkorak ini sangat jelas menunjukkan ciri-ciri Homo erectus. Hal ini terlihat pada bagian kening yang sudah mulai menonjol, penyempitan jelas di daerah orbit mata, maupun bagian belakang tengkorak yang sangat runcing. Dewasa ini, seandainya hasil pertanggalan tersebut benar adanya, maka teng-korak anak Homo erectus dari Mojokerto ini merupakan individu Homo erectus yang paling purba di Indonesia.

\section{- Ngandong, Blora, Jawa Tengah}

Ngandong merupakan nama sebuah desa di tepian Bengawan Solo dalam wilayah Kabupaten Blora, Jawa Tengah. Desa yang terletak jauh di pedalaman, di tengah-tengah hutan jati ini, menjadi dikenal para ilmuwan berkat penemuan fosil-fosil manusia purba. Bermula pada tahun 1931, ketika Ter Haar mengadakan pemetaan di daerah ini, pada suatu lekukan Bengawan Solo menemukan endapan teras yang mengandung fosil-fosil vertebrata. Pada tahun itu juga dia mengadakan penggalian pada salah satu teras yang berada 20 meter di atas aliran sungai sekarang (Oppenoorth, 1932), dan menemukan 2 buah atap tengkorak manusia purba. Penggalian yang berlangsung hingga Desember 1933 bersama-sama Oppenoorth 
dan von Koenigswald menemukan beberapa atap tengkorak lainnya hingga akhimya mencapai 11 tengkorak manusia, sebuah pecahan parietal, dan 5 buah tulang infra-tengkorak (termasuk 2 tibia). Temuan ini kemudian dideskripsikanoleh Oppenoorth sebagai Homo soloensis.

Tengkorak Homo erectus Ngandong berukuran besar dengan volume otak rata-rata $1100 \mathrm{cc}$, ciri yang lebih berevolusi dibandingkan dengan Homo erectus dari Sangiran maupun Trinil. Ciri lebih maju ini juga ditunjukkan oleh bentuk atap tengkorak yang lebih bundar dan lebih tinggi. Dengan demikian otak Manusia Ngandong lebih berkembang dibandingkan kelompok yang pernah hidup di Sangiran. Apabila dikait-kan dengan 3 tingkat evolusi yang pernah terjadi di Indonesia, posisi Homo erectus Ngandong berada pada bagian paling akhir, sehingga tengkorak-tengkorak tersebut merupakan tengkorak Homo erectus yang paling berevolusi, paling maju.

Pertanggalan radiometrikNgandong sangat bervariasi sehingga hingga kini masih tetap dalam kontroversi (Bartstra et al., 1988). Von Koenigswald mempertanggalkan lapisan teras pengandung artefak situs ini dari Plestosen Atas berdasarkan fosil-fosil vertebrata yang dikandungannya. Dalam konteks ini menarik perkiraan pertanggalan yang diajukan sementara pihak yang berkisar antara 100,000 dan 80,000 BP (Sémah et al., 1990).

\section{- Sambungmacan, Sragen, Jawa Tengah}

Sambungmacan terletak di tepian Bengawan Solo, di Desa Ngadirojo, sekitar 2 kilometer ke arah utara, sebelum Mantingan. Penemuan berupa fosil atap tengkorak Homo erectus bersama-sama dengan fosil-fosil tulang binatang di situs ini berlangsung secara kebetulan, ketika pada tahun 1973, masyarakat menggali kanal yang memotong aliran Bengawan Solo untuk mencegah banjir. Lokasi yang tepat dari penemuan tidak diketahui sehingga menyulitkan penentuan umumya.

Tengkorak Homo erectus dari Sambungmacan 1 sangat tebal dengan insersi otot yang telah berkembang. Meski menunjukkan ciri kekar, Sambungmacan 1 
merupakan individu dewasa perempuan, dan menunjukkan ciri morfologis serta ukuran yang berdekatan dengan ciri tengkorak-tengkorak Ngandong, terutama dengan Ngandong 1, Ngandong 7, dan Ngandong 14 (Jacob, 1984). Atap tengkoraknya lebih tinggi dan lebih bundar dari Homo erectus Sangiran, dan menyamai atap tengkorak yang berasal dari Ngandong. Demikian pula perkiraan volume otaknya, termasuk dalam variasi volume otak Homo erectus Ngandong. Dari berbagai segi, Homo erectus Sambungmacan merupakan bagian dari Homo erectus Ngandong, yang dalam posisi evolutifnya berada pada Homo erectus yang paling maju. Dari situs ini, telah ditemukan pula 2 buah atap tengkorak sejenis lainnya, yaitu Sambungmacan 2 dan Sambungmacan 3.

\section{- Patiayam, Kudus, Jawa Tengah}

Sebuah premolar dan beberapa pecahan atap tengkorak ditemukan di suatu seri stratigrafi berfosil oleh S. Sartono dan Y. Zaim di Kubah Patiayam, kaki Gunung Muria, pada tahun 1979. Menurut Zaim (1989), seri stratigrafi tersebut terdiri atas endapan laut di bagian bawah, dan endapan kontinental yang merupakan hasil aktivitas Gunung Muria, di bagian atas. Di atas salah satu bukitnya, Gunung Slumprit, terdapat endapan volkano-sedimenter berupa konkresi breksi volkanik yang diikuti oleh pengendapan puluhan meter pasir dan lempung tufaan, yang berkaitan dengan pusat eruptif Patiayam dan Gunung Muria. Fosil-fosil manusia tersebut ditemukan di tengah-tengah fosil mamalia dan reptil dari pasir dan lempung tufaan, yang melalui metode pertanggalan Potassium-Argon, menunjukkan usia $0.85 \pm 0.02$ juta tahun. Ciri stratigrafi tersebut memungkinkan untuk mensejajarkan temuan dari Patiayam dengan Seri Kabuh di Sangiran.

\section{- Ngawi, Jawa Timur}

Sebuah tengkorak yang lengkap dengan dasar tengkoraknya, telah ditemukan di pinggir Bengawan Solo tahun 1987, yaitu di Desa Selopuro, Ngawi, Jawa Timur. Penemuan ini lepas dari konteks stratigrafi. Sartono menduga bahwa temuan ini mungkin berasal dari salah satu sistem teras Bengawan Solo di Desa Pitu yang mengalir di daerah Ngawi (Sartono, 1991). Teras ini diperkirakan mempunyai usia yang sama dengan teras Ngandong. 
Karakter umum tengkorak Ngawi 1 seperti misalnya morfologi squama frontalis, torus supra-orbitalis, penyempitan belakang orbit, lunas sagittalisnya, posisi lebal maksimal, dan juga torus angularis pada bagian parietalnya menunjukkan kesamaan dengan tengkorak-tengkorak Ngandong dan Sambungmacan (Widianto et al., 2001). Analisis kladistik atas fosil Ngawi ini dengan membandingkan 31 spesimen dari berbagai tempat di dunia juga menguatkan posisinya sebagai bagian dari kelompok Ngandong dan Sambungmacan (Widianto and Zeitoun, 2003).

\section{DAFTAR PUSTAKA}

Bartstra, Gert-Jan, Santoso Sugondho \& Albert van der Wijk, "Ngandong man, age and artifacts", Journal of Human Evolution, 17, 1988, hal. 325-337;

Campbell, B.G., 1965. "The nomenclature of the Hominidae ", Royal Anthrop. Inst. Of Great Britain and Ireland : hal 1-28.

De Terra, H., 1943. « Pleistocene geology on early man in Java », Trans. of the Americ. Phil. Soc., Vol. XXXII : 437-466.

De Vos, John, et al., 1982. «The importance of the Dubois collection reconsidered ", Mod. Quatern. Res. In SE Asia, 7 : 35-63.

Duyfjes, J., 1936. "Zur geologie und stratigraphie des Kendenggebietes zwischen Trinil und Soerabaja (Java) ", De Ingenieur in Nederlandsch Indie, 8 : 136-149.

Howells, W.W., 1973. Evolution of the genus Homo, 188 hal.

Jacob, T., 1984. « The fossil skull cup from Sambungmachan and its implication to human evolution ", Berkala Bioanthropologi Indonesia V (1) : 19-29. 
Jacob, T., and G.H Curtis, 1971. « Preliminary pottassium argon dating of early man in Java ", Contr. Un. Calif. Archaeolo. Res. Facil., $12: 50$.

Koenigswald, G.H.R, von, 1940. « Neue Pithecanthropus funde 1936-1938. Ein beitrag zur kenntnis der praehominiden », Wetensch. Medel., $28: 1-205$

Marks, P., 1953. "Preliminary note on the discovery of a new jaw of Meganthropus von Koenigswald in the Lower-Middle Pleistocene of Sangiran, Central Java, Indo. ", Journ. Natur. Sci., 109 : 2633.

Mayr, E., 1950. "Taxonomic categories in fossil hominids", Cold Spring Harbor Symposia on Quantitative Biology, 25 : Origin and Evolution of Man : 109-118.

Oppenoorth, W.F.F., 1932. «Homo (javanthropus) soloensis, een Plistocene mensch van Java ", Wetensch. Med. Dienst Mijnb. Ned. Indie, $20: 49-74$.

Sartono, S., 1991. "New Homo erectus skull from Ngawi, East Java : relation to Upper Pleistocene terraces in Java", Indo-Pacific Prehistory Association, no. 11 : 14-22.

Sémah. A.M, 1982. "Variation de la vegetation du Plio-Pleistocene sur les sites de Sangiran et Sambungmacan (Java Central) par l'analyse pollinique », Premier Congres International de Paleontolagie Humaine : 559-577;

Sémah, A.M., 1986. "Le millieu naturel lors du premiers peuplement de Java, resultats de l'analyse pollinique, ", These de Doctorat es Science Naturelles, Vol. I et II : 189 hal. 
Sémah, F., 1986. «Le peuplement ancien de Java. Ebouch d'un cadre chronologique », L »Anthropologie Tome 90, No. 3 : hal. 359-400.

Sémah, F., A-M. Sémah, Tony Djubiantono, Mereka Menemukan Pulau Jawa, Jakarta : Puslit Arkenas, 1990, hal. 19.

Suzuki. M., et al., 1982. "A chronological framing for the Sangiran hominids-fundamental study by the flourine dating method ", Bull. Nat. Sci. Mus. Tokyo, D, 8 : hal. 1-53.

Swisher III, C.C, W.J. Rink, S.C. Anton, H.P. Schwarcz, G.H. Curtis, A. Suprijo, Widiasmoro, 1996. "Latest Homo erectus of Java: Potential contemporaneity with Homo sapiens in Southeast Asia", Science, vol. 274 : hal. 1870- 1873.

Swisher III, C.C., GH Curtis, T. Jacob, A.G Getty, A. Suprijo, Widiasmoro, 1994. "Age of the earliest known hominids in Java, Indonesia", Science, 25 February 1994 : 1118-1121.

Van Es, L.J.C, 1931. The Age of the Pithecanthropus, 141 hal.

Weidenreich, F., 1945. "Giant early man from Java and South China", Anthrop. Papers Am. Mus. Nat. Hist. 40 : 205-290.

Widianto, Harry, 1993. "Unité et Diversité des Homindés Fossiles de Java : Présentation de Restes Humains Fossiles Inédits", Desertasi. Institut de Paleéontologie Humaine, Paris, Perancis, 284 hal.

Widianto, Harry and V. Zeitoun, 2003. "Morphological description, biometry, and phylogenetic position of the skull of Ngawi 1 (East Java, Indonesia) ", International Journal of Osteoarchaeology, 13 : 339-351. 
Widianto, Harry, A.M Sémah, T. Djubiantono, and F. Sémah, 1994. « $A$ tentative reconstruction of human cranial remains of Hanoman 1 from Bukuran, Sangiran, Indonesia " Cour. Forsch. Ins. Sanckenberg, Vol 171 : 47-59.

Widianto, Harry, D. Grimaud-Hervé, S. Sartono, 2001. "The evolutionary position of the Ngawi calvaria", Indo-Pacific Prehistory Association Bulletin $21: 162$.

Widianto, Harry, T. Simanjuntak, and Budianto Toha, 2001. "The discovery of stone implements in the grenzbank: new insights into the chronology of the Sangiran flake industry " Bull. of the IndoPacific Prehistory Association,Vol. 21 :159-161.

Zaim, M.Y., 1989. "Les formations volcano-sédimentaires quaternaries de la region de Patiayam, Central Java, Indoneésie. Milieu de sédimentation et mineralogy", Thèse de Doctorat du Muséum National d'Histoire Naturelle, Paris : 264 hal. 